\title{
OTOBÜS SEKTÖRÜNÜN
}

\section{DEĞER ZİNCİRİ ANALIZZiNE} YÖNELİK NİTEL BİR

\section{ARAŞTIRMA: ÜRETIMM}

\section{İŞLETMESİ ÖRNEĞİ}

\section{Fahri ÖZSUNGUR}

Dok.Öğr., Hacettepe Üniversitesi

Aile ve Tüketici Bilimleri Bölümü

ticaretsicili@gmail.com

\author{
Hacettepe Üniversitesi \\ iktisadi ve Idari Bilimler \\ Fakültesi Dergisi, \\ Cilt 36, Sayı 2, 2018, \\ s. $95-123$
}

$\ddot{\mathbf{O}}$ z: $\mathrm{Bu}$ çalışmada otobüs sektörünün değer zinciri, üretim sektöründe bir otobüs işletmesi üzerinde vaka çalışması yapılarak belirlenmiştir. Yapılandırılmış sorularla 20 şirket yetkilisi ile mülakat yapılmış, gözlem ve veri çeşitleme yöntemi ile şirket hakkında detaylı bilgiler edinilmiştir. Şirketin güçlü ve zayıf yönleri ile firsat ve tehditler belirlenmiştir. Değer zinciri analiz yöntemi ile otobüs işletmesinin temel değer zincirinin petrol ve demir cevheri ile başladığ 1 , plastik ve kauçuk, demir, çelik ve metal ile bu hammaddelerin üretime doğru ilerlediği, plastik, metal ve elektronik parçaların sistem tedarikçilerine sevk edildiği, üretimle birlikte imalatçılardan satıcılara ve nihai tüketiciye doğru bir akış gerçekleştiği tespit edilmiştir. Çalışmaya konu otobüs işletmesi örneğinde tedarik lojistiği, operasyon, sevkiyat lojistiği, pazarlama ve satış ile hizmet otobüs işletmesi değer zincirinde temel faaliyetler olarak ortaya konulmuştur. Tedarik, güvenlik, teknoloji geliştirme, konfor, insan kaynakları yönetimi ve işletme altyapısı ise destek sağlama faaliyetleri olarak belirlenmiştir. Bu akış sonucunda kar marjı ve rekabet gücü ortaya çıkmaktadır.

Anahtar Sözcükler: Değer zinciri analizi, kaizen yaklaşımı, git- gör- uygula tekniği, otobüs sektörü, endüstriyel yörünge etkisi 


\section{A QUALITATIVE}

\begin{tabular}{|c|c|}
\hline RESEARCH FOR VALUE & $\begin{array}{l}\text { Hacettepe University } \\
\text { Journal of Economics } \\
\text { and Administrative }\end{array}$ \\
\hline CHAIN ANALYSIS OF BUS & $\begin{array}{c}\text { Sciences } \\
\text { Vol. 36, Issue 2, 2018, } \\
\text { pp. 95-123 }\end{array}$ \\
\hline
\end{tabular}

SECTOR: EXAMPLE OF

pp. 95-123

\section{MANUFACTURING COMPANY}

\author{
Fahri ÖZSUNGUR \\ Phd. Student, Hacettepe University \\ The Department of Family and \\ Consumer Sciences \\ ticaretsicili@gmail.com
}

bstract: In this study, the value chain of
bus sector is determined by conducting a
case study on a bus company in manufacturing industry. 20 company executives are interviewed with structured questions and detailed information about the company is obtained through observation and the data diversification method. The strengths and weaknesses of company are identified with opportunities and threats. By the value chain analysis method, it is identified that the main value chain of bus company starts with petroleum and iron ore; then, the raw materials, as plastic, rubber, iron, steel and metal, progress towards production; after that the produced plastic, metal and electronic parts are shipped to system suppliers and, consequently, the product flows from manufacturer to seller and ultimate consumer. Procurement logistics, operation, shipment logistics, marketing and sales, and service are identified as the main activities in the bus operation value chain. Supply, security, technology development, comfort, human resources management and operational infrastructure are defined as the support activities. This flow determines the company's profit margins and competitive power.

Keywords: Value chain analysis, kaizen approach, genchi genbutsu technique, bus industry, industrial orbit effect. 


\section{Gİiș}

Karayolunun çok eski tarihlerden bu yana tercih edilen taşıma sistemi olduğu gerçeği, günümüz insan taşımacılığı anlayışında da ağırlıklı tercih sebebini oluşturmaktadır. Havayolu şirketlerinin artış göstermesi, bilet fiyatlarının neredeyse karayolu taşımacıllı̆ı ile aynı düzeye gelmesi, teknolojik gelişmeler tüketici tercihlerini etkilemiştir. Havaalanlarının şehir dışında bulunması, şehir merkezlerine ulaşım konusunda karayolu taşımacılığının tercih edilmesine neden olmaktadır. Özellikle hava alanı ya da su yolu ile taşımacılıkta limanların şehir merkezlerine uzaklığı, karayolu taşımacılığını sürekli tercih edilen bir tüketim unsuru haline getirmiş̧ir.

Karayolu taşımacilı̆̆ında uzun ya da orta mesafeli yollarda otobüs ve midibüs gibi vasıtalar kullanılmaktadır. $\mathrm{Bu}$ vasıtaların üretimi ve müşterilere sunumu, sürdürülebilir rekabet avantajının kazanılması açısından önemlidir. Taşıma hizmetini satın alan nihai tüketicilerin arzu, istek ve ihtiyaçlarına uygun seyahatlerin gerçekleştirilebilmesi, üretimin müşteri odaklı gerçekleştirilebilmesine bağlıdır. Zira, üretimle başlayan süreç, nihai tüketim memnuniyeti ile son bulabilmelidir. Bu bağlamda müşterinin algıladığı değerin belirlenmesi gerekmektedir. Sadece hizmet sunan bir işletmenin müşteri memnuniyeti ile üretime doğrudan etki etmesi düşünülemeyeceğinden, hizmetin sunulduğu aracın değiştirilmesi ile memnun kalmama sorunu aşılabilir. Ancak aynı durum üretimi gerçekleştiren bir işletme için mümkün olmayabilir. Zira üretim sonucunda stokta bekletilen ürünlerdeki memnuniyetsizlik, önemli zararlarla sonuçlanabilir (Ruhl, 1997; IMA, 1999: 6). Bu durumda, üretimi gerçekleştiren bir işletmenin nihai tüketime kadar geçen süreci iyi tespit etmesi ve geri beslemelerle sorunlara hızlı ve akılcı bir şekilde çözüm üretmesi gerekir. İşletmenin mevcut durumu ve stratejik yönetim bağlamında nereye gittiği, bu sorunların çözülmesinde önemli bir yöntem olan değer zinciri analizi ile ortaya konulabilir. Literatürde sektörel açıdan değer zinciri analizine yönelik bu yöndeki çalışmalar sınırlı sayıdadır. Ayrıca değer zinciri analizi ile yapılıış çalışmaların otomobil, tekstil, gıda, havayolu, lojistik sektörlerinde ağılıklı oluşu ve otobüs sektörüne ilişkin yapılmış çalışmaların tespit edilememesi çalışmanın önemini ve literatüre katkısını ortaya koymaktadır (Kuyucak, Şengür, 2009; Eraslan, 2008; Taylor, Fearne, 2009; Bhatnagar, Teo, 2009; Howeieson vd., 2016; Taylor, 2005; Janssen, Sol, 2000; Crain, Abraham, 2008; Y1lmaz, Bititci, 2006).

\section{REKABET AVANTAJI YARATMA YOLLARI}

Bir işletmenin pazardaki rekabet gücünün belirlenmesi, işletme kârlllığının sektörel ortalamanın altında ya da üstünde olup olmadığının tespitine bağlıdır. Uzun vadede ortalamanın üzerinde seyreden kârll1lk işletmeye, sürdürülebilir rekabet avantajı sağlar. Bir işletmenin sahip olabileceği iki temel rekabet avantajı vardır: düşük maliyet ya da farklılaşma (Porter, 1985: 11). Kârlılı̆ıı rekabet avantajına dönüşebilmesi 
maliyet liderliği, farklılık ve odaklaşmaya bağlıdır. Verimlilik, örgütsel sistemin çıktısı olması ile tüketilmek için oluşturulması arasındaki ilişkidir (Harris, 1994: 136). İşletme stratejisinin doğru şekilde seçimi ve uygulanması işletmenin rekabet avantajını artıırı.

\subsection{Başarıı Strateji Hazırlanması için Gereklilikler}

\subsubsection{Projeye Katılım (Müşterek Çalışma)}

İşletmelerin üretim maliyetlerinin düşürülmesi ve verimliliğin artırılması süreklilik için önemlidir. Üretim verimliliğ̈inin artırılması kadar üretim hatlarında meydana getirilecek verimlilik ve iyileştirme faaliyetleri de önemlidir. Uzun vadeli hedefler bağlamında hangi ürünlerin hangi dış ya da iç kaynaklarla üretileceği konusu işletmelerde çözüme kavuşturulmalı ve böylelikle gereksiz ürün çeşitliliği önlenmelidir (Engelbrecht vd., 2017: 997). Başarılı bir strateji için, tedarikçi ve müşterinin de içinde bulunduğu sistemsel döngüde görevli tüm çalışanların işletme stratejisi için geliştirilen projede yer alması gerekir. Zira, müşterek çalışma değişik fikirlerin sunulmasına imkan sağlayabileceği gibi, üretime yönelik çalışan, müşteri ya da tedarikçilerin işletme ve üretim sistemine bakış açısına pozitif değer katacaktır. Üretimin işletme temelli olduğu kanısının üzerinde sistemsel döngünün bir ürünü olduğu varsayımı üretim stratejisi için daha anlamlı projelerin üretilmesine olanak sağlayacaktır. Böylelikle, müşteri, tedarikçi ya da çalışanlar kendilerine külfet yükleyeceğini bildiği halde bir başkasına yarar sağlayıcı hareket olan özgeci (altruist) tavır sergileyecek, üretim stratejisini daha anlamlı kılacaktır (Artto $v d$., 2008: 53; Alsudiri $v d ., 2013: 598$ ).

\subsubsection{Problem Çözümüne Kaizen Yaklaşımı}

Kaizen yaklaşımı, sürekli iyileştirme sürecini ifade eden, Japonca "Kai" ve "Zen" kelimelerinden oluşan bir yaşam biçimi ve yönetim felsefesidir. Problem çözümünde zamanın boşa harcanmaması, tam zamanında teslim, üretilen ürün yük dengesinin tür ve miktara göre gerçekleştirilmesi, doğru ekipmanla standardize edilmiş çalışmanın varlığı önemlidir (Takahashi $v d$., 2007: 1; Imai, 2012: 59). Bu felsefe ve yönetim tekniği ile işletme, faaliyetlerini gelişim ve değişime uyum sağlayacak şekilde sürekli bir iyileştirme sürecine adapte eder. William Edwards Deming iyileştirme sürecini 14 yönetim ilkesi ile açıklamıştır:

- Ürün ve hizmetin iyileştirilebilmesi, rekabet edebilir olmak, işin sürekliliği, iş sağlamak için amaçlarda süreklilik yarat.

- Yeni felsefeyi kabul edin ve hayata geçirin. Değişime açık olunmalıdır.

- Kaliteyi elde etmek için denetime bağlilığa son verin.

- Fiyat etiketi temelli iş uygulamalarına son verin.

- Kalite ve verimliliği geliştirmek ve böylece maliyeti düşürmek için üretim ve hizmet sistemini sürekli ve kalıcı olarak geliştirin.

- İşle ilgili eğitim programları oluşturun. 
- İnsanlara, alet ve makinelere yardımcı olmak ve işin iyi yapılması amacıyla liderlik oluşturun.

- Etkin bir çalışma için korkulardan uzaklaşın.

- Departmanlar arasındaki bariyerleri kaldırın. Üretim ya da hizmet sunulmasında gerçekleşen problemleri önceden tespit edebilmek için; araştırma, dizayn, satış ve üretimde çalışan insanlar ekip olarak çalışmalıdır.

- Sloganlar, tavsiye ve hedefleri işgücü için bir tarafa bırakın. Sloganlar, muhalif ilişkiler yaratır.

- Sayıları, sayısal amaçları, kotaları bir yana bırakın.

- Çalışanların ustalıklarıyla gurur duymasını ve haklarını engelleyen bariyerleri ortadan kaldırın.

- Dinamik bir kendini geliştirme ve eğitim programı oluşturun.

- Dönüşümü başarabilmek için herkesi örgütleyin (Takahashi vd., 2007). Zira, dönüşüm herkesin işidir (Deming, 2000: 24).

\subsubsection{Git- Gör- Uygula (Genchi Genbutsu) Tekniği}

Yaratıc1lık ve cesaret girişimcilikte risk almayı gerektiren unsurlardır. Yönetim stratejisinin, uzun vadeli hedeflerin amaca yönelik gerçekleştirilmesine dayalı yollar bütünü olduğu düşünüldüğünde, salt bu iki unsurun benimsenmesi işletmenin sürekliliğini sağlamayacaktır. Bir işletmeyi sürekli kılabilecek, rakiplerine karş1 onu avantajlı kılacak, pazardaki konumunun korunmasını sağlayacak sürekli iyileştirme stratejisi ve bu stratejide yaşanabilecek olası aksaklıkların giderilmesinde uygulanacak bazı metotların benimsenmesi gerekmektedir. Japon kaynaklı bir yönetim stratejisi olan "Genchi Genbutsu", sorunun kaynağına odaklanmayı ve gözlemi öngörür (Monden $v d$., 2013: 32). Zira sorunların sebepleri farklıdır ve aynı sorunun farklı zamanlarda meydana gelmesinde aynı kaynağın neden olduğu inancı her zaman doğru olmayabilir. Zaman içinde gerçekleşen aynı sorunun farklı nedenleri olabilir. Torna makinesinin cıvata dişlisi açmasında, aynaya yerleştirilen çelik kesici aleti kullanılır. Cıvata dişlisinde oluşabilecek olası diş hatası ayna, çelik kesici kııılması, cıvatanın özellikleri, devir sayısı ayar kollarında meydana gelen bir aksaklık ya da yanlış ayar, punta ucu kayması veya hatası gibi birçok nedenden kaynaklanabilir. Bu hatanın gözlemlenen iki, üç ya da dört hata sayısında tespit edilen nedeninin ayna olması, beşinci hatanın da ayna olacağı anlamına gelmeyecektir. Atölyenin bir bütün olarak düşünülmesi, hatanın olası nedenlerinin yerinde gözlem yolu ile tespit edilmesi hatayı çözme açısından daha gerçekçi ve doğru yaklaşım olacaktır. İstatistiksel verilerle yapılan tespitlerin sonraki hatalara uygulanması kaynak israfına ve maliyete yol açabilir. "Git- Gör- Uygula" tekniği her ne kadar zaman israfına yol açacakmış izlenimi verse de verimlilik açısından en doğru yol olduğu söylenebilir. Zira bu teknik ile kaybedilecek zamanla meydana gelen işgücü kaybı, ileride doğabilecek olası istatistik hataları sonucunda meydana gelebilecek işgücü, mamul, sipariş gibi kayıplar ile zincirleme bir zarara tercih edilmelidir. Siparişin doğru ve zamanında teslimi, işletmenin müşteri gözündeki değeri 
için önemlidir. Rekabet avantajının sürekliliği ve iyileştirme sürecinin işleyiş̧inin doğru şekilde gerçekleşmesi için sorunu kaynağında çözmek gerekir. Özellikle üretim sürecinde parçaların montajı esnasında meydana gelebilecek olası aksaklıkların önceden tespit edilip, kaynağında çözülmesi defolu ürün zararını da asgariye indirecektir (Marksberry, 2011: 142).

\subsection{4. Üretim Stratejileri}

Bir işletmede yönetim stratejisi geliştirmeye başlayabilmek için öncelikle amaçların tespit edilmesi gerekir. Zira amaçların belirlenmesi planların yönünü belirler (Kobu, 1993: 45; Raia, 1963: 30). İşletmenin amaçlarının gerçekleştirilmesi ise dört temel rekabet boyutu olan maliyet, kalite, zaman ve esneklik unsurları ile başa çıkabilme yeteneğine bağlıdır. İşletme maliyetlerini rakiplerine ve finansal çıktılarına oranla düşük tutabilirse, müşterilerine hizmet ve mal sunumlarını zamanında ve doğru bir şekilde gerçekleştirebilirse, müşteri geri bildirimlerini esas alacak şekilde ürün ve hizmetleri kalitesini yükseltir ve sürekliliğini sağlarsa, dış çevredeki değişimlere uyum sağlarsa geliştirilen strateji amaca ulaşır.

\subsubsection{Organizasyonda Orantılı Odaklaşma}

Organizasyonda odaklaşma, stratejinin belirli bir faktörde yoğunlaşmasını ifade eder. Yüksek kalite, düşük maliyet, esneklik ve müşteri ihtiyaçlarına cevap verebilme organizasyonda odaklaşma faktörlerine örnek verilebilir (Nieto- Rodriguez, 2012: 9). Faktörler üzerinde odaklanma öncesinde yöneticiler yatay ve dikey örgütsel yapıyı düşünmelidir (Gardner, 2004: 43). Organizasyon, şeffaf olmalıdır (Cochran, 2006: 36). Odaklanma, avantajlı olduğu kadar riskler de içerir. En önemli risk, bilinçsiz odaklanmadır. Kalıplara bağlı kalmak, organizasyonun yatay ve dikey yapılanmasının bu odaklanma ile yaşayacağı sorunlar, bu sorunların üretime yansımaları planlama öncesi düşünülmelidir. Organizasyonda odaklaşma bu şekilde gerçekleştirilebilir.

\subsubsection{Dış Çevre Analizi}

Çevre, örgütlerin faaliyetlerini, yapılanmalarını etkileyen önemli bir unsurdur. İşletme, iş çevresi ve diğer dış çevresinin sunduğu firsatları ve tehditleri belirlemek amacıyla dış çevreyi doğru şekilde izleyebilmelidir. Pazardaki ekonomik, sosyal çevre işletme tarafından incelenmeli sosyal sınıflar içinde ve arasındaki etkileşim göz önünde tutulmalıdır. Özellikle toplumsal, kültürel, sinıfsal beklentiler üretim ve teslim aşamasında çevreyi doğru algılayabilmek için önemlidir. Rekabetçi bir piyasada rakiplere karşı avantaj sağlayabilmenin temel kurallarından biri de dış çevrenin doğru analizidir. Fırsat ve tehditler, dış çevrenin analizi ile ortaya konabilir (Artto $v d$., 2017: 111).

Çevre esasen bakış açısına bağlıdır. Nereden, nasıl ve neye baktığınızla ilgilidir. İşletmenin çevreyi tespitinde bakış açısının önemi çevrenin üç kategoride incelenmesine 
neden olur. Robert Albanese' e göre diş çevre; gerçek, algılanan ve uygulama çevresi olarak üçe ayrılmaktadır (Albanese, 1988: 144).

\subsubsection{Gerçek Dış Çevre}

İşletmeyi ilgilendiren ancak işletme dış çevresinde yer alan unsurlar toplamıdır. Rakip işletmeler, yasal düzenlemeler, tüketiciler gerçek dış çevrenin unsurlarından bazılarıdır. Gerçek dış çevre, işletmenin planlarının gerçekleştirilmesine etki eder.

\subsubsection{Algılanan Dı̊ş Çevre}

İşletme yöneticilerinden her biri birey olmalarından dolayı çevreyi farklı algılamaktadır. Dış çevrede gelişen olaylar bazı yöneticiler için firsat bazıları için tehdit olarak algılanabilir. Dış çevrenin nasıl algılandığı, algılanan ile var olan gerçek arasındaki farklılıklar işletme ve üretim stratejisini etkiler (Artto $v d ., 2017: 111$ )

\subsubsection{Uygulama Çevresi}

İşletme yöneticileri, işletme ve üretim stratejilerini belirlerken çizdikleri yolun hangi çevresel alana hitap edeceğini belirlerler. Belirleme esasen alternatifler arasında yapılacak bir seçimdir. Yönetici görev, amaç ve stratejilerini seçtikleri çevreye uygularlar. Bazen arzu duyulan çevre ile seçilen çevre birbirinden farklı olabilir. Yönetici kendi penceresinden seçmeyi arzuladığı çevrenin işletmeye uygun olmadığını yapılan araştırmalarla tespit edebilir ya da işletmenin niteliği bu davranışa sevk edebilir. Örneğin, anonim şirkette yönetim kurulu üyelerinin ortaklar dışından seçilmiş olması durumunda ortakların yönetim kurulu üzerindeki etkisi baskın duruma gelebilir. Böyle durumlarda yönetici seçmeyi arzuladığ çevreyi tercih edemez (Antony vd., 2012: 33).

\subsubsection{Güçlü Yönlerin Tespiti (Core Competencies)- Temel Yetkinlikler}

İşletme stratejisini belirlerken kendine özgü, farkl1lık yaratan güçlü yönlerini tespit edebilmelidir (Ferrell, Hartline, 2012: 85). İşletmenin iş işleyişi, iç ve diş çevresinde gelişen olaylardan haberdar olma hızı, müşteri ve tedarikçi geri beslemelerinin doğru şekilde işletmeye aktarılmasını sağlama, bilgi akışının doğru birimlerde gerçekleşmesi, geri beslemelere verilen yanıtların karşılığını buluyor olması gibi yetkinlikler işletmenin temel yetkinliklerinin iskeletini oluşturan ve bu yetkinliklere değer kazandıran yetkinliklerdir. Bir işletme, gerek yönetim stratejisini belirlerken, gerekse çevre analizi ile elde etmiş olduğu bilgilere karşı güçlü ve zayıf yönlerini tespit edebilmelidir. Çevresel analiz ile ortaya çıan firsat ve tehditler işletme tarafından doğru şekilde analiz edilmeli, doğru birimlerde değerlendirilmeleri sağlanmalı ve gereken önlem ya da girişimlerin önü açılmalıdır (Böhm, 2008: 6). 


\section{DEĞER ZINCİṘ ANALİŻ}

Her işletme ürünlerinin tasarım, üretim, pazarlama, teslim, taşıma işlerinin gerçekleştirildiği, birbirine bağlı faaliyetler bütünüdür. Bir işletmenin değer zinciri, birbirine bağlı faaliyetler sistemidir (Bhatnagar ve Teo, 2009; Porter, 2008: 76, 492). Her işletmenin değer zinciri üretim hattı, müşterileri, faaliyetini sürdürdüğü coğrafya, dağıtım kanalları, faaliyetin sürdürüldüğü yerin kültürel- ekonomik- sosyal özelliklerine göre değişiklik gösterir (Taylor, Fearne, 2009; Porter, 1985: 36). Analizin doğru yapılması ise değer etkinliğinin belirlenmesine bağlıdır. Değer etkinliğinin belirlenmesi, teknolojik ve stratejik olarak farklılık gösteren faaliyetlerin ayrılmasını gerektirir. Zira, değer etkinliği ve mali sınıflandırmalar nadiren benzerlik gösterir. Genel giderler, direkt işçilik giderleri gibi mali sınıflandırmalar farklı teknolojilerdeki faaliyetlerde kümelenir ve aynı faaliyetlerin maliyetlerine ayrılır. Burada temel amaç, üretilen ürünlerin maliyetlerinin teknolojik etkenler altında oluşan maliyetin hangi ürün ya da faaliyet koluna ne derecede etki ettiği, dolayısı ile işletmenin tamamına yansıyan faaliyet değerinin tespit edilmesidir. Böylece işletmenin üretim aşamasındaki değerin son zincire olan etkileri de tespit edilmiş olacaktır ki bu da işletmenin bu yöndeki güçlü ya da zayıf yönlerinin ortaya konulmasında önemli bir rol oynayacaktır (Howeieson $v d$., 2016).

Değer zinciri analizinde, analizin amaç ve hedeflerinin tespitinde zincir kelimesinin önemlidir. Analize başlamadan önce, analiz yapılırken ve nihai raporlama sürecinde işletmenin bir bütün olduğu ve işletmenin alt unsurlarının zincirin birer halkası olduğu unutulmamalıdır. Değer kelimesi ise bu halkaları/ bağı güçlü kılan, her bir halkaya anlam katan, simgesel, sayısal ve algısal oluşumlardır. Porter değeri, işletmenin tüketiciye kazandırdığı faydaya karşıllı tüketicinin ödemeyi kabullendiği bedel olarak ifade etmektedir (Porter, 1985: 38). Her ne kadar değer hakkında bedel ile ifade edilen bir cümle kurulmuşsa da esasen kazanılan fayda ve razı olunan bedel ifadeleri değer zincirinde sadece sayısal verilere yer verilmediğini göstermektedir. Bu nedenle değer zinciri analizinde sayısal veriler kadar algı da önemlidir. Zira işletme, matematiksel bir bütünden daha fazlasıdır (Taylor, 2005).

Bir işletmeye değer sağlama dört adımda gerçekleşebilir: Değer seçimi, değer yaratma, değer yayma/ iletme, değer artırma (Gupta $v d$., 2007: 63). İşletmeler, rekabet ortamında mevcut değerler arasından kendilerine değer yüklemesi yaparlar. $\mathrm{Bu}$ yükleme, işletmenin, ürünün, ortakların, müşterilerin, coğrafyanın, ülkenin, milliyetin, dinin ya da başkaca faktörlerin etkisi altında oluşturulmuş ve daha önce başkaca işletmelerce kendilerine yüklenmiş değerlerdir. İşletme, vizyonu hakkında bilgi edinilmesini sağlayacak misyon çalışmalarında bu şekilde bir yüklemede bulunur. İşletmenin ürettiği ürüne yüklediği bedel de değeri oluşturur. Seçilen değerin işletme, ürün ya da hizmetle ilgisinin azalması, mevcut değerler arasında yerini bulamama ya da 
başkaca nedenlerle kendine özgü bir değer yaratılabilir. Üretim, pazarlama, tasarım faaliyetleri ile işletme kendine özgü bir değer yaratır. İşletmenin yaratılan ve seçilen değerleri müşteriye reklam, pazarlama, dağıtım kanalları, internet, sosyal ağlar kullanılarak iletilir. Böylece müşteri algısı da oluşturulmuş olur. Üretilen ürün, sunulan hizmet, marka ve işletme ile ilgili iletilen değerler hakkında müşteri ve diğer çevrede oluşan algı tespit edilerek değer artırma çabalarına girişilir. Değer artırma çalışmaları tutundurma stratejileri için de önemli bir yer tutar. Markaya bağl1lık, rekabet avantajı kazanma, müşteri odaklı stratejiler geliştirme ve değer artırmaya bağlıdır (Janssen ve Sol, 2000).

Porter sektörde rekabet için gerekli temel faaliyetler için beş eşdeğer kategori ileri sürmüştür: Tedarik lojistiği, operasyon, sevkiyat lojistiği, pazarlama ve satış, hizmet.

\subsection{Temel Faaliyetler}

Temel faaliyetler, ürün temelli faaliyetlerdir. $\mathrm{Bu}$ faaliyetler ürün girdilerinin işletmeye girişinden nihai ürün elde edilinceye kadar geçen süreçte gerçekleştirilen ürün odaklı faaliyetlerdir.

\subsubsection{Tedarik Lojistiği}

Mal kabulü, depolama, girdilerin ürüne dağıtımı ile ilgili faaliyetler tedarik lojistiğini oluşturur. Örnek olarak malzeme boşaltma, depolama, antrepolama, stok kontrolü, araç çizelgeleme, iadeler verilebilir.

\subsubsection{Operasyon/ İşlem}

Ürünün makinede işlenmesi, paketlenmesi, montajı, bakımı, kontrolü, baskısı ve üretime yardımcı diğer işlemler gibi nihai ürüne dönüssen girdilerle ilgili faaliyetler operasyonu oluşturur.

\subsubsection{Sevkiyat Lojistiği}

Tahsilat, depolama, ürünün müş̧erilere fiziksel dağıtımı sevkiyat lojistiğini oluşturur. Örnek olarak nihai ürünün ardiyede bekletilmesi, malzemelerin taşınmak üzere yüklenmesi, sevkiyata dair işlemler, siparişin hazırlanması ve planlanması verilebilir (Porter, 1986: 37).

\subsubsection{Pazarlama ve Satıș}

Müşterilerin işletmenin ürünlerini satın almalarını teşvik edecek faaliyetlerden olan reklam, promosyon, satış ekibi oluşturma, fiyat belirleme, kanal seçimi ve ilişkileri gibi faaliyetler pazarlama ve satışı oluşturur (Crain, Abraham, 2008). 


\subsubsection{Hizmet}

Ürün değerinin geliştirilmesi ve sürekliliğinin sağlanması için ürün kurulumu, tamir, eğitim, ürün parça temini, garanti gibi hizmetlerin sunulmasına yönelik faaliyetlerdir (Porter, 1985: 40; Porter, Teisberg, 2006: 403).

Tüm bu kategoriler bir işletmenin sektördeki rekabet avantajının ortaya çıkarılmasını sağlar. Ancak, her bir kategorinin önem derecesi işletmenin özelliklerine, ürettiği ürün ya da sunduğu hizmete, sektörel özelliklere göre değişebilir. Bir distribütör için tedarik ya da sevkiyat lojistiği çok önemli olmayabilir. Bir banka için pazarlama ve satı̧s kategorisine ağılık vermek gerekebilir. Bu durum, ilgili kategorinin seçilerek diğer kategorilerin elenmesini gerektirmez. Her işletme için geliştirilecek stratejilerde ve yapılacak analizlerde kategorilerin ağırlık dereceleri belirlenmelidir. Değer analizinde atlanacak bir kategori ya da değer, rekabet avantajında kayıplara neden olabilir.

\subsection{Destek Sağlama Faaliyetleri}

Destek sağlama faaliyetleri, ürüne yardımcı, işletmenin iç işleyişine odaklanmış faaliyetler bütünüdür. Destek sağlama faaliyetleri üretim ya da hizmetin gerçekleştirilmesine yardımcı, işletmenin üretim veya hizmet dışındaki fonksiyonlarına odaklı faaliyetlerdir.

\subsubsection{Tedarik}

Tedarik, işletmenin değer zincirinde kullanılan girdi alımlarının işlevidir. Hammadde, gereçler ve diğer tüketilebilir malzemeler satın alınan girdileri oluşturur. Satın alınan girdiler temel faaliyetlerle ilgilidir. Örneklemek gerekirse araştırma geliştirme için anket formları alımı, bu birime ait araçlar satın alınan girdileri oluşturur.

\subsubsection{Teknoloji Geliş̧irme}

Teknoloji, rekabet avantajında önemli bir faktördür. Teknoloji geliştirme ile maliyetlerin düşürülmesine yönelik faaliyetler gerçekleştirilebilir. Araştırma- geliştirme, uzmanlaşma, yöntemler, süreç yönetimi gibi faaliyetler teknoloji geliştirme faaliyetleri içinde yer alır. Özellikle iyileştirme sürecinde, ürüne dayalı geliştirme faaliyetleri teknoloji geliştirmeden etkilenir. Hizmet sunumu ya da ürün üretiminde bilgi kaynağına erişme, bilgi yönetimi ve bilginin gizliliğinde teknoloji geliştirme faaliyetleri kullanılır.

\subsection{3. İnsan Kaynakları Yönetimi}

$\mathrm{Bu}$ yönetim biçimi, kaynağını ekonomik bir güç olan insandan alır. Kıt kaynakların yönetimi, mevcut işin yürütülmesi, işin işleyişinde iyileştirme çabaları, hatalı ürün üretiminin kaynağını bulma, kaos yönetimi, işe alım, hukuk kurallarının uygulanması, personel özlük uygulamaları gibi bir çok konuda işletmeye destek sağlayıcı faaliyetler yürütür. 


\subsection{4. İşletme Altyapısı}

İşletmeler finansal, hukuksal ve yönetimsel yapılarını güvence altına almak ister. Zira, bu durum organizasyonu daha ileriye taşıyacak ve böylece rakiplerine karşı avantaj sağlamasını sağlayabilecektir. İşletme alt yapısı, işletmenin muhasebe, hukuk, finans, stratejik planlama, kalite yönetimi, yönetim işlevleri, kamu ile olan ilişkilerden oluşur. İşletme altyapısı faaliyetleri, altyapının işlevlerinin işletmeyi birçok yönden ileriye taşıyabilecek özelliktedir. Bu bağlamda yapılan faaliyetler, işletmeye değer sağlar (Shekhar, 2010: 116). Değer zinciri analizi güçlü ve zayıf yönlerin belirlenmesine olanak sağlayacağından, işletme altyapısının tespiti gereklidir (Porter,1985: 41).

\section{OTOBÜS ENDÜSTRİSININ ÖZELLIKKLERİ}

Otobüs endüstrisi; bölgesel, ulusal, yönetimsel, stratejik, ölçeklik, ekonomik büyüklük, teknoloji, üretim türü, tasarım yönlerinden farkl1lıklar gösteren devlet ekonomisine katkı sunan bir sanayi türüdür.

\subsection{Genel Karakteristikleri}

Otobüs üretimi hassas, yoğun ve bütünleşik bir endüstridir. Bileşikleri, tedrikçileri ve üretim sürecinden dolayı karmaşı ir yapıya sahiptir. Bu endüstri, diğerlerine göre daha geniş aralıklarda yer alan üretim hattı nedeniyle yüksek işbirliği gerektirir (Jan, Hsiao, 2004: 1146).

\section{2. Ölçek Ekonomisi}

Sabit üretim maliyetleri, otobüs üretiminde yüksektir. Birim başına düşen maliyetin üretim sayısının azlığında yüksek oluşu, kü̧̈ük üretim ölçeğinde dezavantaj sağlar. İşletmenin pazarda tutunabilmesi ve gelişebilmesi için ölçeği yeterince yüksek olmalıdır (Schmidt, Gary, 2002: 359).

\subsection{Yüksek Yatırım ve Maliyet}

Otobüs üretimi sermaye yoğun ve teknoloji ile yüksek yatırımlar gerektirir. Yeni bir model geliştirmek ya da eski sistemi terk etmek büyük maliyetler ve yatırımlar gerektirir. Bu endüstri bilgi akışındaki güvenlik, sistemsel güvenlik, mekanik güvenlik sistemleri gerektirir. Bilgi akışının doğru olabilmesi, iletişim sisteminin kalitesine ve güvenilirliğine bağlıdır. Tüm bu gereksinimler, sektörde pazara girişe engel unsurları oluşturmaktadır.

\subsection{Endüstriler Arası Çekim Gücü (Yörünge Etkisi)}

Bileşenlerinin farklı endüstri türlerinde gerçekleştirilen üretime bağlı olması, otobüs endüstrisini tıpk1 otomotiv sektöründe olduğu gibi merkez konumuna getirmektedir. Otobüsün bileşenlerini üreten diğer işletmeler, bu endüstrinin tedarik 
zincirine eklenmek için bir çaba içine girer. Öncelikle diğer işletmelerin otobüs üretim işletmesi çevresinde fabrika yerleştirme sürecini başlatmaları, başkaca sanayi kollarını bu yörüngeye çeker. Bu nedenle, biz bu çekim gücünün merkezinde olan işletme çevresine diğer işletmelerin yerleşmesini yörüngeye yerleşme ve bu etkiye de yörünge etkisi adını vermekteyiz. Bu etki sadece işletmelerle sınırlı kalmamakta, kamuyu, sosyal ve fiziksel çevreyi de etkilemektedir.

\section{5. İşgücü Kaynağı}

Otobüs üretiminin kompleks yapısı, üretim hattının üretilen otobüsün türüne göre değişiklik gösterebilmesi işgücüne duyulan gereksinimi artırır.

\subsection{Teknoloji Transferi}

Gelişmekte olan ülkelerde teknolojik dönüşüm gerekir. Üretim ve tasarım eksiklikleri işletmeleri ve yatırımcıları iş ortaklıklarına ya da teknoloji transferine yöneltir. Teknolojiyi transfer edecek ülkelerin, transfer edilecek ülkelere göre gerçekleştirdikleri uygunluk ve uyum işlemleri uygun teknoloji ile açılanmaktadır. Teknolojinin az gelişmiş ülkelerin çevresi ile uyum sağlayabilmesi araştırma- geliştirme faaliyetlerinin gerçekleştirilmesini gerektirebilir. Çoğu zaman, bu faaliyetlerin gerçekleştirileceği tesisler çok uluslu şirketler tarafından kurulmaktadır.

\subsection{Kamusal Destekler}

Otobüs üretiminin büyümesi gelişmekte olan ülkeler için, kamusal desteklere ve kalkınma politikalarına bağlıdır. Özellikle devlet teşvikleri, yatırım politikaları, ihracat kolaylıkları, girişimci destekleri bu büyümeye katkı sağlar. Yerel üretimin artı̧ıı toplam ekonomiye de fayda sağlar.

Şekil 1.' den de anlaşılacağı üzere otobüs işletmesi temel değer zincirinde petrol ve demir cevheri ile başlamakta, plastik ve kauçuk, demir, çelik ve metal ile bu hammaddeler üretime doğru ilerlemektedir. Plastik, metal ve elektronik parçalar sistem tedarikçilerine sevk edilmekte, üretimle birlikte imalatçılardan satıcılara ve nihai tüketiciye doğru bir akış gerçekleşmektedir. 


\section{Şekil 1. Değer Zinciri Analizi Yapısı}

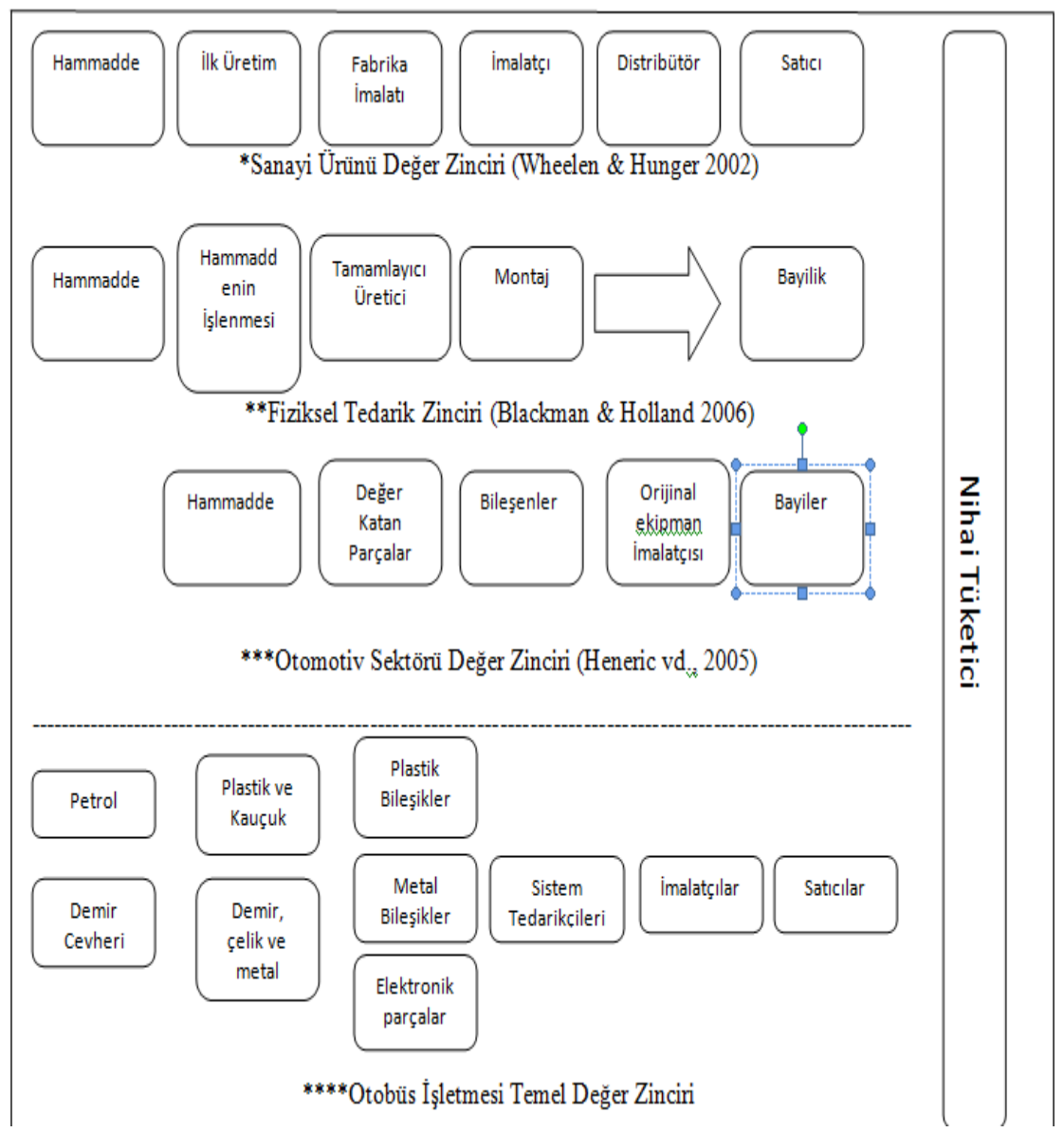

Kaynak: Lind $v d .$, (2012: 95).

Şekil 1. ve Şekil 2.' de görüleceği üzere bir işletmenin ürettiği ürün ve hizmetin nihai tüketiciye ulaştığ oluşturur. Şekil 2.' de belirtildiği üzere tedarik lojistiği, operasyon/işlem, sevkiyat lojistiği, pazarlama ve satış ile hizmet/ servis otobüs işletmesi değer zincirinde temel faaliyetler olarak tespit edilmiştir. Tedarik, güvenlik, teknoloji geliştirme, konfor, insan kaynakları yönetimi ve işletme altyapısı ise destek sağlama faaliyetleri olarak belirlenmiştir. Bu akış sonucunda kar marjı ve rekabet gücü ortaya çıkmaktadır. 


\section{Şekil 2. Otobüs İşletmesi Değer Zinciri Sistemi}

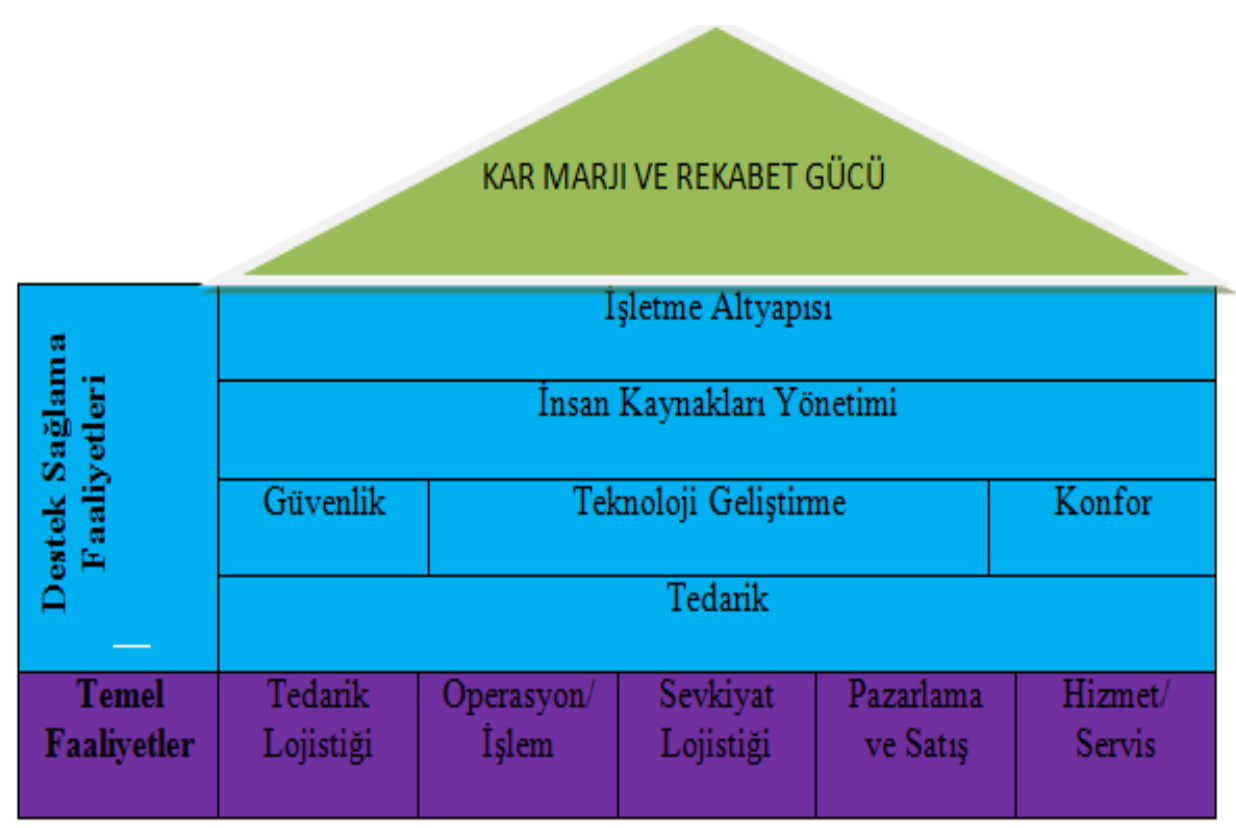

Kaynak: Porter' dan (1985) uyarlanmıştır.

\section{ARAŞTIRMA}

\subsection{Araştırmanın Amacı}

Araştırmanın amacı, otobüs üreten işletmelerin sektörel değer zincirini belirleyerek rekabet gücünün sağlanma yöntemlerini ortaya koymaktır. Otobüs üretim işletmelerinin kuruluş, yeni pazarlara girme, ürün çeşitlendirme gibi faaliyetlerinin büyük yatırımlar gerektirmesi stratejilerini doğru şekilde belirlemesini gerektirmektedir. İşletmelerin rekabet gücünü yakalayabilmeleri ve sürdürebilmeleri, sistemlerini doğru tanımalarına bağlıdır. Bu nedenle çalışmada, vaka analizi ile işletmenin zayıf yönlerini belirlemekle yetinilmemiş özellikle güçlü yanların olumsuzluklarına da değinilerek kârlılığın sürekli gerçekleşmesi için yol gösterilmeye çalışılmıştır.

\subsection{Araştırmanın Yöntemi}

Bir işletmenin gerçek finansal verilerine ulaşabilmek oldukça zordur. Özellikle maliyetler ve yönetimsel stratejiler hakkında gerçek verilere ulaşabilmek çoğu zaman mümkün olmamaktadır. Bunun nedeni, işletmelerin pazarda tutunabilme, işletmenin bilgilerinin açığa çıkması ile rekabet avantajlarının dezavantaja dönüşmesi riskini ortadan kaldırmak, paylaşılması istenen bilgilerin sağlanmasının belirli bir maliyete ve işgücüne neden olması ve bazen de yönetimsel bakış açısıdır. Özellikle yönetimsel bakış açısı, tepe yönetimin bilgi paylaşımı konusunda cimri/kapalı ya da cömert/ şeffaf olması 
ile ilgilidir. Paylaşıma açık olmayan yönetim risk almak istemez, işletmenin yönetimi konusunda sürekli bir korku içindedir. Bu durum genelde, strateji oluşumunda rakipler karşısında farklılık yaratma gücünün düşüklüğü ile ilgilidir. Rekabet durumunda kaybetme korkusu, yönetimin farklılık yaratma konusundaki zayıflı̆ğ ile artış gösterir. $\mathrm{Bu}$ durum, değer zinciri analizinin önemini de ortaya çıkarır. Niteliksel (qualitative) araştırma yönteminin yapılandırılmış görüşme, veri toplama yaklaşımı ve gözlem teknikleri kullanılmıştır (Gerring, 2004). Önceden belirlenmiş sorular aynı sıra ile tüm katılımcılara sorulmuştur (Gall vd., 1996). Çalışmanın sonunda "Ekler" başlığı altındaki Ek1' de yer alan yapılandırılmış sorular Porter'ın (1985) "Değer Zinciri Analizi" yöntemi esas alınarak hazırlanmıştır. Yapılandırılmış görüşme veri toplama tekniği ile 20 işletme yetkilisiyle görüşme yapılmış, alınan cevaplara ve araştırma konusuna göre detaylara inilmiş ve notlar alınmıştır (Punch, 2005). Bununla "ne" ve "nasıll" cevaplarına ulaşılmak amaçlanmıştır (Yin, 2009; Gillham, 2000). Araştırmada veri çeşitleme yöntemi kullanılarak gözlem ve başkaca vasıtalarla elde edilen veriler görüşme verileriyle karşılaştırılmıştır. Böylece farklı kaynaklardan beslenen veriler karşılaştırılarak güvenilirlik düzeyleri karşılaştırılmıştır (Patton, 1990; Türnüklü, 2001). Ayrıca işletmenin üretim yeri yetkililerle birlikte gezilmiş, fotoğraf çekmek yasak olduğu için gözlem yapmakla yetinilmiş ve durum tespiti yapılmıştır (Suchman, 1987). Yapılan gözlem üretim hatları, yemekhane, iş görenlerin çalıştıkları servisler, dinlenme yerlerinde gerçekleşmiş̧ir. İşletmeden alınan veriler ve edinilen bilgilerin doğruluğu web sayfasından, bu işletme ile ilgili üçüncü kişilerce hazırlanmış raporlardan teyit edilmiştir.

\subsection{Araştırma Soruları}

Araştırmada otobüs sektörünün değer zinciri ile analizinde cevapları aranan sorular aşağıdaki gibidir:

S1. Otobüs sektörünün değer zinciri sistemi hangi faaliyetlerden oluşmaktadır?

S2. Otobüs sektörünün değer zincirinde kilit faktör nedir?

S3. Otobüs sektöründe faaliyet gösteren bir işletmenin güçlü ve zayıf yönleri nelerdir?

S4. Otobüs sektöründe faaliyet gösteren bir işletmeye değer sağlayan unsur ve faaliyetler nelerdir?

\subsection{Katılımcıların Demografik Bilgileri}

Yapılandırılmış görüşme veri toplama tekniği ile gerçekleştirilen çalışmanın 20 katılımcısına ait demografik bilgiler Tablo 1.' de verilmektedir. 
Tablo 1. Demografik Bilgiler Tablosu

\begin{tabular}{|l|l|l|l|l|l|}
\hline & $\begin{array}{l}\text { F (Sıklık) } \\
\mathbf{N = 2 0}\end{array}$ & $\begin{array}{l}(\boldsymbol{\%}) \\
\text { Yüzde }\end{array}$ & & $\begin{array}{l}\text { F (Sıklık) } \\
\mathbf{N = 2 0}\end{array}$ & $\begin{array}{l}\text { (\%) } \\
\text { Yüzde }\end{array}$ \\
\hline Cinsiyet & & & Yaş & & \\
\hline Erkek & 13 & 65 & $25-35$ & 4 & 20 \\
\hline Kadın & 7 & 35 & $36-45$ & 7 & 35 \\
\hline Medeni Durum & & & $46-55$ & 8 & 40 \\
\hline Hiç evlenmemiş/Bekar & 9 & 45 & 55 ' ten fazla & 1 & 5 \\
\hline Evli & 9 & 45 & Ĕgitim Düzeyi & & \\
\hline Boşanmış & 2 & 10 & Üniversite & 20 & 100 \\
\hline
\end{tabular}

Katılımcıların \% 65' i erkek, \% 35' i kadın, \% 40' 1 46-55 yaş, \% 20' si 25-35 yaş, \% 35' i 36-45 yaş, \% 5' i 55' ten fazla yaşa sahip, \% 45' i bekar, \% 45' i evli, \% 10' u boşanmış ve tamamı üniversite mezunudur.

\section{5. Çalışmanın Kısıtları}

Çalışmanın en önemli kısıtı işletmeye dair bilgilere erişimde yaşanan zorluklardır. Özellikle Ar- Ge birimine ulaşmak mümkün olmamış, diğer birimlerden, internet üzerinden ve bünyesinde olduğu holding ve şirketler grubundan bilgi edinilmiştir. Üretim hattının tamamı gezilememiştir. Finansal datalar konusunda da gerçek verilere ulaşılamamış sadece yakın veriler elde edilebilmiştir. Araştırmaya katılan her kişiye ilgi ve bilgi düzeyine uygun sorular spontane şekilde sorulmuş, alınan cevapların farklılığı durumunda gözlem ve veri çeşitleme yöntemi ile farklı kaynaklar kullanılarak doğru verilere ulaşılmaya çalışı1lmıştır (Patton, 1990).

\subsection{Otobüs Üretim Sektöründe Yer Alan Firmalar ve Kapasiteleri}

Türkiye' de üretim gerçekleştiren ticari işletmelerin $11^{\prime}$ i otobüs ve minibüs üretmektedir. Bu işletmelerin beşi ise otobüs üretmektedir (Deniz, 2009: 14). Rakiplere ait üretim kapasitesi ve son beş yıllık üretim adetleri Tablo 2.' de verilmiş̧ir.

Tablo 2. Türkiye Otobüs İşletmelerinin Üretim Kapasitesi ve Üretim Adetleri

Tablosu

\begin{tabular}{|c|c|c|c|c|c|c|}
\hline & \multicolumn{5}{|c|}{ YILLARA GÖRE ÜRETIM ADETLERI } & $\begin{array}{c}\text { ÜRETIM } \\
\text { KAPASITTESİ }\end{array}$ \\
\hline İșletme Adı & $\mathbf{2 0 1 2}$ & $\mathbf{2 0 1 3}$ & $\mathbf{2 0 1 4}$ & $\mathbf{2 0 1 5}$ & $\mathbf{2 0 1 6}$ & $\mathbf{2 0 1 7}$ \\
\hline A & 3336 & 4001 & 3686 & 4253 & 4231 & 4500 \\
\hline B & 1134 & 1300 & 1051 & 1743 & 1826 & 2400 \\
\hline $\begin{array}{c}\text { C (HEDEF } \\
\text { İȘLTME) }\end{array}$ & $\mathbf{9 5 7}$ & $\mathbf{1 1 8 6}$ & $\mathbf{1 1 0 5}$ & $\mathbf{1 2 3 3}$ & $\mathbf{1 0 3 4}$ & $\mathbf{2 0 0 0}$ \\
\hline D & 619 & 1224 & 406 & 714 & 665 & 1000 \\
\hline E & 166 & 58 & 151 & 462 & 236 & 1070 \\
\hline F & 8 & 576 & 43 & 384 & 91 & 2025 \\
\hline G & 207 & - & - & - & - & - \\
\hline
\end{tabular}

Kaynak: OSD (2017).

Tablo 2.' de görüleceği üzere Türkiye otobüs üretim pazarında analizi yapılan işletmenin üretim kapasitesi rakiplerine göre dördüncü sırada yer almaktadır. Yıllara

Hacettepe University Journal of Economics and Administrative Sciences |

Vol 36, Issue 2, 2018

110 
göre otobüs üretim adetlerinin rakip işletmelerde artışla sonuçlandığı görülmektedir. Hedef işletme de üretim artışı göstererek rakiplerine karşı artı değer kazanmıştır. Bu veriler, siparişlerin verilme aşamasında müşterilere güvenilirlik kazandırma açısından önemlidir. Zira, müşteriler ürüne bağlı özellikler, maliyet ve kalite ile birlikte üretim adetinin düşüş veya artışını da izlemektedir.

\subsection{Otobüs Üretim Sektöründe Değer Zinciri}

Tablo 3. Türkiye Otomotiv Sanayii Firmalarının Ürüne Göre Üretim Adetleri ve İhracatları Tablosu

\begin{tabular}{|c|c|c|c|c|c|c|c|}
\hline \multirow[b]{2}{*}{ YIL } & \multicolumn{7}{|c|}{ OTOMOTIV SANAYIII FİRMALARININ ÜRETİM ADETLERİ } \\
\hline & 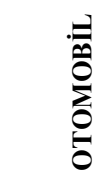 & 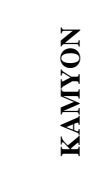 & 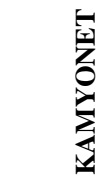 & $\begin{array}{l}: \infty \\
: 0 \\
0 \\
0 \\
0\end{array}$ & : & 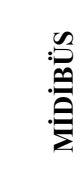 & 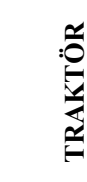 \\
\hline 2012 & 577.296 & 29.129 & 426.633 & 6.427 & 29.335 & 4.158 & 42.255 \\
\hline 2013 & 633.604 & 30.082 & 410.556 & 8.345 & 37.750 & 5.197 & 40.509 \\
\hline 2014 & 733.439 & 29.909 & 359.911 & 6.442 & 35.420 & 5.324 & 48.403 \\
\hline 2015 & 791.027 & 35.838 & 468.933 & 8.789 & 47.078 & 7.131 & 51.238 \\
\hline 2016 & 950.888 & 17.374 & 461.637 & 8.083 & 44.415 & 3.330 & 50.746 \\
\hline \multirow[t]{2}{*}{ YIL } & \multicolumn{7}{|c|}{ OTOMOTIV SANAYİ FİRMALARININ İHRACATLARI } \\
\hline & 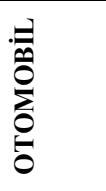 & $\begin{array}{l}Z \\
\vdots \\
\sum \\
\sum\end{array}$ & 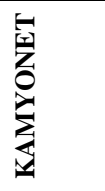 & 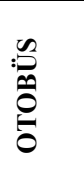 & 兄 & 兄 & 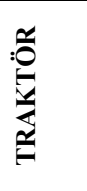 \\
\hline 2012 & 383.850 & 2.697 & 321.206 & 4.059 & 16.590 & 1.189 & 15.424 \\
\hline 2013 & 459.250 & 2.942 & 323.036 & 3.933 & 34.645 & 1.013 & 14.906 \\
\hline 2014 & 581.652 & 1.279 & 270.224 & 4.481 & 26.453 & 946 & 17.014 \\
\hline 2015 & 604.839 & 1.406 & 341.801 & 5.677 & 38.252 & 448 & 14.932 \\
\hline 2016 & 745.781 & 5.487 & 347.979 & 6.468 & 34.794 & 915 & 13.643 \\
\hline
\end{tabular}

Kaynak: OSD (2017).

2012 y1lı otomotiv sanayii firmalarının toplam üretim miktarı 1.115.233, 2013 y1l 1.166.043, 2014 y1l 1.218.848, 2015 y1l 1.410.034, 2016 y1l 1.536.473' tür. 2012 yılı otomotiv sanayii firmalarının toplam ihracat adedi 745.015 ihracat değeri 12.068.047.592, 2013 y1l toplam ihracat adedi 839.725 ihracat değeri 13.334.189.014, 2014 yll toplam ihracat adedi 902.049 ihracat değeri 13.758.755.536, 2015 yılı toplam ihracat adedi 1.007.355 ihracat değeri 13.181.475.078, 2016 yll toplam ihracat adedi 1.155.067 ihracat değeri 15.739 .729 .793 ' tür. 2015 yllına kadar toplamda otobüs üretiminin, 2016 yllına kadar ise ihracat adetlerinin artış gösterdiği görülmektedir.

Otomotiv sektörü, başka sektörlerin ürettiği mamüllerden yararlanır. Bu nedenle birçok sektörle ilişki içindedir. Otobüs üretimi işletmeleri üretim öncesinde; öncesinde demir çelik, petro-kimya, plastik, tekstil, cam, elektronik, makine imalat, elektrik 
sektörlerinden üretime esas teşkil edecek ürünleri temin etmek zorundadır. Üretim sonrasında satış aşaması ve sonrasında ise pazarlama/ bayi, servis/ yedek parça, finans/ sigorta, akaryakıt sektörleri ile ilişki içindedir. Savunma, tarım, turizm, ulaştırma, alt yapı, inşaat sektörleri otobüs üretimi ile ilişki içinde olan başkaca sektörler arasında yer alır. Tüm bu sayılanlar; otomotiv sektörünün etki altında kaldığı, hammadde tedarikini sağlayan, işletme tesisine etki eden, işletmenin üretimini etkileyen, finansal ve ekonomik konumunu belirleyen, yatırımlar üzerinde teşvik edici ya da caydırıcı rol oynayan sektörlerdir. Etkileşim içinde bulunulan sektörlerin birinde yaşanacak aksaklık ya da iyileşme, şirketin bütününe etki edebilir. Bu zincir neticesinde ortaya çıkan değer, nihai tüketiciye ulaşan güvenli ve etkin karayolu insan taşımacılığıdır.

\section{5. İŞLETMENIN DEĞER ZİNCIRİ ANALİZi}

Bir işletmenin değer zinciri temel ve destek sağlama faaliyetleri olarak iki temel başlıkta incelenir. İki temel başlıkta yapılacak incelemeler işletmeye değer sağlayan faaliyetlerin tespitini sağlayacaktır.

\subsection{Temel Faaliyetler}

\subsubsection{Tedarik Lojistiği}

Otobüsün bileşenlerini oluşturan ana maddelerin işletmeye kabulü, depolama, girdilerin ürüne dağıtımı ile ilgili faaliyetler tedarik lojistiğini oluşturmaktadır. Otobüsün cam, motor, kapıları gibi malzemelerin boşaltılması, depolanması, stok kontrolü, araç çizelgeleme ve iadeler otobüs işletmesinin tedarik lojistiğinde yer almaktadır.

Yerli üretim elektrikli otobüs geliştirme projeleri için işbirliği projelerine imza atılmıştır. Müşteri bağlılığına önem verilmektedir. Sürüş güvenliği, konfor ve maliyet azlığı konularına önem verilmektedir. Yerli otobüs üreten işletme, kendi segmentinde pazar payını \% 10' a ulaştırmıştır. İşletmenin servis ağı 70 civarındadır. Bu anlamda satış sonrası hizmetlere önem verdiğini söylemek mümkündür. Servis çalışanlarının eğitimine dikkat edilmektedir. Yerli üretime ilişkin sürekli ilişki içinde olduğu tedarikçi ağı mevcuttur. Servis için gerekli yedek parçalar bu ağdan sağlanmaktadır.

İşletme, İş sağlığı ve güvenliği ile çevre kirliliğine dikkat etmektedir. İş süreçlerine katma değer sağlayan aksesuarlar yan sanayi merkezinde üretilmektedir.

\subsubsection{Operasyon/ İșlem.}

Otobüsün parçalarının makinelerle montajı, bakımı, kontrolü, baskısı ve boyası gibi nihai ürüne dönüşen girdilerle ilgili faaliyetler operasyonu oluşturmaktadır. 
Fosfat ve katoferez tesisi ile üretim kalitesine değer kazandırılmaya çalışılmıştır. İş güvenliği ve çevresel etkili riskleri azaltan, ürün kalitesini artıran ve maliyetlere olumlu yansıyan, tamamen yeni teknoloji ve otomasyonun kullanıldığı bu tesisler ile üretim akış şemasına pozitif değer kazandırılmıştır.

\subsubsection{Sevkiyat Lojistiği.}

Tahsilat, depolama, otobüslerin montaj sonrasında müşterilere fiziksel dağıtımı sevkiyat lojistiğini oluşturmaktadır. Örnek olarak otobüsün otobüs parklarında bekletilmesi, sevkiyata dair işlemler, siparişin hazırlanması ve planlanması sevkiyat lojistiğinde yer almaktadır.

\subsubsection{Pazarlama ve Satış.}

Müşterilerin işletmenin ürünü olan otobüsü satın almalarını teşvik edecek faaliyetlerden olan reklam, promosyon, satış ekibi oluşturma, fiyat belirleme, kanal seçimi ve ilişkileri gibi faaliyetler pazarlama ve satışı oluşturmaktadır. 66 farklı ülkeye ürünlerini ihraç eden işletme, Adana' da $555.000 \mathrm{~m}^{2}$ alanda üretimini sürdürmektedir. Finansal datalar uzmanlık gerektirdiğinden çeşitli ürün gamına sahip şirketin muhasebe müdürlüğü ile görüşülmüş ve sayısal veriler elde edilmiş ancak bununla yetinilmeyerek, iş görenlerle de finansal verilerin çıktılarının doğruluğu hakkında yaklaşık görüşler elde edilmiştir. Şirketin yıllık otobüs (midibüs dahil) üretim kapasitesi 4000, yıllık araç üretim kapasitesi ise 11.500' dür. 1970 öncesinde kurulmuş olan şirket, yurtdışı kaynaklı bir şirketle 1980' li yıllarda distribütörlük, lisanslı üretim ve teknik destek anlaşmaları imzalamıştır. Otobüs, kamyon, midibüs üreterek, üretim hacmini ve şirket etkinliğini artıran işletme 2000' li yıllara gelindiğinde Almanya' da şirket açarak üretime devam etmiştir. Şirket, bünyesinde çalışmalar sürdürülen Ar- Ge merkezi ile yapmakta olduğu çalışmalarının ve yönetim stratejilerinin bir sonucu olarak ürün gamını girmiş olduğu yurtdışı pazarlarına göre artırmakta ve geliştirmektedir. Özel ve kamu sektörü şirketin satış ağı içinde yer almaktadır. İş makinesi üretimi de gerçekleştiren şirket, 2010' lu yıllarda otomotiv ve iş makinesi faaliyet ayrımına gitmiştir. Fransa, Almanya, İtalya, Avusturya, İsveç, Litvanya, Benelux, Amerika Birleşik Devletleri' nde üretilen ürün ve üretici şirket bilinmektedir. Tüm otobüs ve midibüs üretiminin \%37'si ihraç edilmiştir. Batı Avrupa ve Amerika'ya ihracatın \%32'si, Doğu Avrupa ve Türkiye Cumhuriyetleri' ne ise \% 32' lik dilimin dışında kalan kısım gerçekleştirilmiştir. Şirket markası, kurumsal kültürünün bir sonucu olarak müşteriler için güven nedenini oluşturmaktadır. Ulusal ve uluslararası fuar ve etkinliklerde marka ve ürün tanıtımları yapılmaktadır. Ana hissedarının ulusal ve uluslararası pazarda tanınmış ve güvenilir bir marka oluşu şirketin pazarda rekabet avantajı kazanmasını ve sürdürülebilirliğini olumlu yönde etkilemiştir. 


\subsubsection{1. İşletmenin Pazarlama ve Satış Verileri}

2014 y1lı satı̧ miktarı 1907 adettir. Yurtiçi otobüs pazarında 2014 yılında \%19' luk bir daralma gerçekleşmiştir. İşletmenin bu pazardaki payı ise \%30' dur. Yurtiçi otobüs pazarındaki otobüs miktarı toplamda 6.350 adettir. İşletmenin pazardaki payı ise \%30’ dur. 2013 yılı işletme pazar payı \%16 iken 2014 yılında bu payın artırılmış olması şirket için artı değerdir. İşletmenin ihracat faaliyetleri 60 'dan fazla ülke ile gerçekleştirilmektedir. 2014 yılı satış geliri 670 milyon TL' dir. 2015 yllının ilk yarısında gerçekleştirilen satış faaliyetleri 1.320 adet gerçekleşmiştir (OSD, 2015). Bu durum şirket stok tüketim performansının pozitif yönde seyrettiğini göstermektedir. İşletmenin ihracat geliri 2014 y1lı için 103 milyon dolardır. 64 ülkeye ihracat yapılmaktadır. Yurtdışı satı̧̧larının \%57.7’ si Avrupa' ya, \%38.8' i A. B. D.' ye, \%3.5’i ise diğer ülkelere gerçekleştirilmektedir.

İşletmenin küresel müşterileri: ABD, Almanya, Avusturya, Azerbaycan, Birleşik Arap Emirlikleri, Belçika, Bulgaristan, Çek Cumhuriyeti, Estonya, Fransa, Gürcistan, Hollanda, Hırvatistan, İngiltere, İsrail, İsveç, İsviçre, İtalya, Kazakistan, Kıbrıs, Kırgızistan, Letonya, Litvanya, Lübnan, Lüksemburg, Malta, Mısır, Makedonya, Norveç, Portekiz, Rusya, Romanya, Sırbistan, Sudan, Slovenya, Slovakya, Suudi Arabistan, Suriye, Tunus, Ukrayna, Ürdün, Yunanistan'dır.

\subsubsection{Hizmet.}

Otobüsün değerinin geliştirilmesi ve sürekliliğinin sağlanması için ürün kurulumu, tamir, eğitim, ürün parça temini, garanti gibi hizmetlerin sunulmasına yönelik faaliyetlerdir.

\subsubsection{Satıs Sonrası Hizmetler}

İşletme, koşulsuz müşteri memnuniyeti ilkesini benimsemektedir. Müşteri şikayetleri çağrı merkezi vasıtasıyla toplanmakta ve bu şekilde çözülmeye çalışılmaktadır. Servislerde tablet uygulaması ile şikayet ve çözüm süreçleri hızlandırılmaya çalışılmıştır. Müşterilere garanti hizmeti vermektedir. Servis ağı ile birlikte üretim ve parça hatalarında yaşanabilecek sorunlarda garanti hizmeti devreye girmektedir. Sarf malzemeleri bu kapsam dışında tutulmuştur. Yedek parça stoğu sorunların çözümü için yeterli düzeydedir.

Müşteri şikayetlerinin değerlendirilebilmesi ve müşteri algısını tespit edebilmek amacı ile işletmenin 350 müşterisine ulaşılmıştır. Müşterilerin $55^{\prime}$ i ile yüz yüze, 295 kişi ile telefonla görüşülmüştür. Şikayetlerin servis şikayetleri ağırlıklı olduğu görülmüştür. Servis hızının yetersiz olduğu yapılan görüşmelerde ortaya çıkarılmıştır. Bir ürünün yakıt tasarruf özelliği olmasına rağmen, özelliği karşılamadığı da bildirilen geri dönüşler arasında yer almaktadır. Müşteri hizmetleri yetkilisine ulaşma sorunu, 
serviste müşteriye ürünü savunan politika geliştirilmiş olması, aracın sıklıkla arıza yaptığı bildirilen şikayetler arasında yer almaktadır.

\subsection{Destek Sağlama Faaliyetleri}

\subsubsection{Tedarik}

Hammadde, gereçler ve diğer tüketilebilir malzemeler satın alınan girdileri oluşturur. Araştırma geliştirme için anket formları alımı, bu birime ait araçlar satın alınan girdileri oluşturur.

\subsubsection{Teknoloji Geliş̧irme}

Teknoloji geliştirme ile maliyetlerin düşürülmesine yönelik faaliyetler gerçekleştirilmektedir. Araştırma- geliştirme, uzmanlaşma, yöntemler, süreç yönetimi gibi faaliyetler teknoloji geliştirme faaliyetleri içinde yer alır. Özellikle iyileştirme sürecinde, ürüne dayalı geliştirme faaliyetleri teknoloji geliştirmeden etkilenir. Hizmet sunumu ya da ürün üretiminde bilgi kaynağına erişme, bilgi yönetimi ve bilginin gizliliğinde teknoloji geliştirme faaliyetleri kullanılır.

\subsubsection{1. Ürünlerin özellikleri}

İşletme ürünlerinde sürüş ve oturma konforu, aracın sarsıntı durumu, yakıt ekonomisi, güç ve performans, yolcu kapasitesinin yüksekliği, iç tasarım, tüketim ömrü, araç parçalarının kalitesi, dayanıklılık, güvenlik, ilk yatırım maliyetinin dönüşü gibi özelliklere dikkat edilmektedir. İşletme, yerli elektrikli otobüs üretimi de gerçekleştirmektedir.

\subsubsection{Araştırma- Geliştirme}

İşletmenin Ar-Ge Departmanı mevcuttur. Üretim, satış, performans, faaliyetler, kârllık gibi ölçümler istatistiki veriler ile bu birimde gerçekleştirilmektedir. Bu departmana giriş ve çıkışlar kontrollü olup bilgi akışı tepe yönetimle sınırlıdır. Departmanın iç işleyiş̧inde akademisyenlerden destek alınmaktadır. Bu departman için ayrılan bütçe yıllık yatırımın \%4,5' lik kısmını oluşturmaktadır.

İşletme, 5746 sayılı Araştırma ve Geliştirme Faaliyetlerinin Desteklenmesi Hakkında Kanun uyarınca Ar- Ge Merkezi belgesine sahip olmuştur. Ar- Ge çalışmaları 75 araştırmacı, 11 teknisyen ve 98 destek personeli ile yürütülmektedir. Bu personel, ürün tasarımından son testlere kadar iş sürecinin doğru yürümesinde çalı̧̧malar sürdürmektedir. İşletme, Ar- Ge birimine diğer personelinden daha farklı imkanlar sunmaktadır. Yüksek lisans ve doktora programlarına katılımı konusunda bu personele verilen ayrıcalık, diğer personele verilmemekle olumsuz bir değere neden olmuştur. Araştırma esnasında katılımcılardan iki kişiye Ar-Ge birimi ile bilgisi olması nedeniyle bu bölüme işletmenin faaliyet zincirleri arasında neden ağırlıklı olarak önem verildiği sorulmuştur. Katılımcılardan biri “..bu birim şirketimizin rakiplerine karşı ayakta durmasın sağlayan ve gizliliği olan en önemli birimdir.” Diğer katılımcı ise, “.. Ar-Ge 
sayesinde yurtdışına açılabildik. Bu birime ağırlık vermeseydik satışlarımızı artıramazdık" şeklinde yanıt vermiştir.

Ar- Ge çalışmalarında öncelik verilen konular arasında araç ve yolcu güvenliği yer almaktadır. Yeni tasarım ürünlerin sürücü destek sistemleri, güvenlik seviyesinin artırılması hedeflenmektedir. Sürücü ve yolcu konforu da diğer öncelikli konular arasında yer almaktadır.

Şehir içi taşımacılığına yönelik körüklü otobüs, güç yönetimi ve araç kontrol sistemi algoritmalarının geliştirilmesi (elektrikli midibüs), araç ağırlığının azaltılması (yüksek dayanımlı düşük alaşımlı çelik kullanımı), için merkezi kontrollü uzaktan arıza tespit ve veri yönetim sistemi gibi projeler geliştirilmektedir. İşletmenin 33 patent, 39 faydalı modeli vardır.

\subsection{4. İnsan Kaynakları Yönetimi.}

Kurum kültürünü ön plana çıkaran işletme, insan kaynaklarına önem vermektedir. İnsan kaynakları politikalarını şu şekilde sıralamak mümkündür:

1. İş görenlerin şahsi ve mesleki yetkinliklerini geliştirmek ve bu yetkinliğin yaşam boyu sürmesini sağlamak

2. İşe alımlarda doğru adaylarla çalışabilmek için etkin bir değerlendirme sistemi kurmak ve bu çalışanları şirkete kazandırmak (Her ne kadar iş gören odaklı bir politika gibi görülse de şirketi yücelten bir politikadır).

3. Ölçüm ve değerlendirme sistemleri oluşturmak, performansın başarı kriterine göre değerlendirilmesi

4. Ölçüm ve değerlendirmede sistemlerinde objektiflik ve anlaşılabilirlik özelliklerine dikkat etmek

5. İş görenlerin bireysel gelişim alanlarını tanımlamak

6. İş görenlere yeni yetkinlikler kazandırmak

7. İş zenginleştirme modelini uygulamak, iş görenlere çalışma alanlarında kariyer ve yükselme olanakları oluşturmak

8. Yönetim anlayışının insana saygı odaklı gelişmesini sağlamak

9. Etik değerlerin tüm iş birimlerinde etkin olmasını sağlamak

\subsubsection{1. İnsan Kaynakları Süreçleri}

Şirket iş görenlerini işe aldıktan sonra İş Sağlı̆̆ ve Güvenliği Eğitimi vermekte, tüm iş alanları kendisine tanıtılmaktadır. İş görenler, işe alınmaları ile birlikte oryantasyon sürecine dahil edilmektedir. $\mathrm{Bu}$ süreçte şirketin organizasyon yapısı, stratejik öncelikleri, misyon, vizyon, hedefleri, değerleri, ve fonksiyonları ile ilgili bazı temel bilgiler verilmektedir. Yeni iş görenlere aynı süreçte şirketin kurumsal kültürü, hangi ürün ve hizmetleri sunduğu, insan kaynakları politikaları, yapılan işle ilgili yasal 
düzenlemeler hakkında bilgi verilmektedir. İş görenlerin iş hukukundan kaynaklanan yasal hakları ile ilgili bilgilendirmenin yapıldığına ilişkin bir bilgiye ulaşılamamıştır. İş görenlerin oryantasyon programı "oryantasyon mentorluğu programı" adı altında sürdürülmektedir. İnsan kaynakları sürecini yöneten yetkili bir katılımcıya oryantasyon mentorluğu programına neden önem verdikleri sorulmuştur. Katılımc1, "Mentorluk bizim için önemli. Çünkü şirketimiz kurumsal bir şirket. Bizler en önemli pazarlama faaliyetlerini aslında çalışanlarımızla yapıyoruz. Sadece Türkiye' ye değil tüm dünyaya açılmış durumdayız. Şirketimizin prensip ve kurallarını, işbirliği ruhumuzu, kurumsal kültürümüzü, kalite politikalarımızı, iç işleyişimizi ilk işe girenlere anlatarak onların işlerini kendi işi gibi sahiplenmesini, doğru işe doğru kişiyi seçmemizi sağlıyor..."

İşletme, kariyer ve yedekleme planları oluşturmuştur. Bu planlar, kariyer yönetimi için geliştirilmiştir. Ödül, terfi gibi imkânlar iş görenlere sunulmaktadır. Bu durumun iş verimliliğini artırdığ 1 şirket tarafından düşünülmektedir. Ancak başarı kriterleri konusunda belirgin bir kıstasa ulaşılamamıştır. İş görenlerin başarısına göre ödüllendirme ve terfi gibi firsatlar sunulmaktadır. Böylelikle iş verimliliğinin artırılması amaçlanmıştır. İşletmenin orta ve uzun vadeli stratejik hedefleri yılda bir kere gözden geçirilmektedir. İş görenler sürekli eğitime tabi tutulmaktadır. Mesleki gelişim imkanı yanında eğitim imkanı her çalışana verilmemektedir.

İşletmede Performans Yönetim Sistemi geliştirilmiştir. $\mathrm{Bu}$ sistem, geribildirimlerle bilgi akışının sağlanması, ilişkilerin yöneticiler ve çalışanlar arasında geliştirilmesini sağlamak, sürekli gelişim kültürünü oluşturmak, adil ücret politikası yürütmek konularını içermektedir. Çalışanların özel sağlık sigortası, bireysel emeklilik, ferdi ve kaza sigortası gibi güvencelerden faydalanması sağlanmıştır.

İş görenler kapsam içi ve kapsam dışı olmak üzere iki gruba ayrılmıştır. Çalışanların \%72' si kapsam içi, \%28' i kapsam dışıdır. İşletmenin \%12' si kadın, \%88' i erkektir. 20- 24 yaş aralığındaki çalışanlar \% 2, 25- 34 yaş aralığındaki çalışanlar \%44, 35- 44 yaş aralığındaki çalışanlar \%48, 45 ve üzeri yaş aralığındaki çalışanlar \% $\% 6^{\prime}$ dır. Kadın çalışanların sayısının azlığı dikkat çekmektedir. 25- 44 yaş aralı̆̆ındaki çalışanların fazlalığı çalışma performansı ve kariyer gelişimi açısından uygun yaş dilimidir. Emek ve teknolojinin eş düzeyli kullanıldığ 1 işletmelerde genç nüfus çalışanların başarı katkısı yüksektir.

\subsection{5. İşletme Altyapısı}

İşletme alt yapısı, işletmenin muhasebe, hukuk, finans, stratejik planlama, kalite yönetimi, yönetim işlevleri, teknik birim, kamu ile olan ilişkilerden oluşmaktadır.

\subsubsection{1. İş Sağlığı ve Güvenliği- Çevre}

İşletme iş sağllğı ve güvenliği ile çevreye önem verecek projeler yürütmektedir. $\mathrm{Bu}$ bağlamda OHSAS 18001, ISO 14001 belgelerini almıştır. Çalışanlar belirli 
aralıklarla iş sağlığı ve güvenliği, çevrenin korunması konularında eğitimlere tabi tutulmaktadır. Üretim hatlarında yaptığımız incelemelerde, iş sağlığ 1 ve güvenliğini tehlikeye düşürebilecek yasal ve fiziksel bir duruma rastlanmamıştır. Ancak sigaranın içilmesi konusunda tedbirlerin eksik olduğu tespit edilmiş̧ir.

\subsubsection{Toplam kalite yaklaşımı}

İşletme, çalışmalarını inovatif ve sürdürülebilir çevre yaklaşımı ile yürütmektedir. Şeffaf ve güvenilir yönetim politikasını benimsenmektedir. Kalite, ürünlerin zamanında teslimi, yasal şartlara uymak konusunda yönetim stratejisi geliştirilmiştir.

\subsubsection{3. İșletmenin Stratejik Hedefleri}

2014 yılı stratejik hedefleri arasında kalite ve kalitesizlik maliyetleri yer almaktadır. Kalite süreçlerinde ve organizasyonlarında görülen eksikliklerin telafi edilebilmesi adına yenilenme sürecine girilmiştir. Kalitenin artırılması için iş süreçleri gözden geçirilmiş ve yenilenmiştir.

\subsubsection{4. İşletmenin Risk Yönetimi}

İşletmenin performans ölçüm sistemleri, kurumsal risk yönetimi, iş modelleri, risk izleme ve raporlama sistemleri mevcuttur.

\subsubsection{Bilgi Güvenliği}

Tescilli bilgi güvenliği sağlamak için kurumsal politikalar geliştirilmiştir. Tepe yönetim ile diğer birimler arasındaki bilgi akışının güvenli ve doğru işleyişi için bazı yazılım ve donanımlar geliştirilmiştir. Bu bağlamda, bazı denetim yöntemlerine başvurulmuştur. İşletmenin ISO 27001 Bilgi Güvenliği Yönetim Sistemi belgesine, ISO 9001: 2008 Kalite Yönetim Sistemlerine sahiptir.

\section{SONUC VE ÖNERILER}

Çalı̧̧mamızda değer zinciri açısından incelenen işletmenin artı değerleri görsel tasarım, maliyet, güvenlik ve konfordur. Güvenlik otomotiv ve otobüs üretiminde kilit faktördür. Özellikle yolcu sayısının fazlalığı, güven faktörünün değer zincirindeki ağırlığını artırmaktadır. Hammaddelerin ve parçaların sağlandığı işletmelere yakınlık, tedarik ağının güçlü olması şirketin gücünü artırmaktadır. Şirketin ürün tasarımı, kalitesi, maliyeti, konfor düzeyi araştırma ve faaliyetleri doğru şekilde düzenlenmektedir. Hammadde, ürün, parça sevkiyatları hızlı, güvenilir, doğru şekilde gerçekleşmektedir. Yatırım projeleri amaçlarla orantılı doğru hedeflere gerçekleştirilmektedir. İhracat verileri ve satış hasılatı işletmeye pozitif değer sağlamakla birlikte, kontrollü üretim ve yeni pazarlarda henüz tam olarak tanınmaması işletmenin zayıf yönünü oluşturmaktadır. 
İşletme finansının, muhasebe bilgi sisteminin, maliyet dağıtımlarının doğru şekilde gerçekleştirilmesi gerekir. Müşteri muhasebesi, müşteri kârlılı̆̆ ve müşteri algısına önem verilmesi gerekmektedir. Teknoloji geliştirme faaliyetleri ve eğitim işletmenin güçlü yanlarıdır. Bu konularda süreklilik sağlanmalıdır. Teknolojinin üretim ve hizmet operasyonlarında kullanımının rekabet gücünü doğrudan etkilediği Türk tekstil ve hazır giyim sektöründe gerçekleştirilen değer zinciri analizinde ortaya konulmuştur (Eraslan, 2008: 328). Havayolu işletmeleriyle ilgili yapılan bir diğer çalışmada, hizmet süreçlerinin değer yaratacak şekilde işletme stratejilerine uygun hale getirilmesi ve müşteri odaklı hizmet sunumunun değer zinciri içindeki yerinin önemli olduğu vurgulanmıştır (Kuyucak, Şengür, 2009: 146).

Pazarlama ve satış ağının geniş olması yüksek yatırımlar gerektirmektedir. Bu durum, yeni pazar arayışlarında çok iyi bir araştırma yapılmasını ve reklam faaliyetlerini artırmayı gerektirmektedir. Bu konuda bağlı bulunulan holding ve kurumsal kültüre sığınmak, doğru bir strateji olmayacaktır. Yapılacak, piyasa araştırma hataları telafisi çok güç zararlara neden olabilecektir. Büyümenin daha kontrollü gerçekleşmesi gerekmektedir. Holding ve kurumsal kültür, pazara girişlerde her zaman etkili sonuçlar doğurmayabilir.

Servis ağının daha geniş, verimli, etkin ve teknolojik olmasına önem verilmesi gerekmektedir. $\mathrm{Bu}$ anlamda müşteri şikayetleri dikkate alınmalıdır. İşçiler arasındaki eğitim ve kariyer olanaklarının Ar- Ge birimindeki çalışanlara sağlanan imkânlarla karşılaştırılması ve bu yönde adil olmayan uygulamaların değiştirilmesi gerekir. Erkek çalışanların fazla olması her ne kadar beden işinde avantaj sağladığı yönünde bir fikir verse de tasarım, Ar- Ge, yönetim birimleri gibi düşünsel etkinliğin yoğun olduğu birimlerde kadın çalışanlara ağırlık verilmesi gerekmektedir. Bunun nedeni, otobüsün sadece bir taşıma aracı değil aynı zamanda görsel bir ürün olduğu gerçeğidir. Otobüste yolculuk eden kadınların azımsanmayacak sayıda olması, hitap edilen müşterilerin sadece alıcılar değil kullanıcılar olduğu gerçeğini de beraberinde getirmektedir.

Git- gör- uygula (genchi genbutsu) tekniği, Kaizen yaklaşımı uygulamaları işletmeye pozitif katkı sağlamaktadır. Üretim aşamasında yaşanan problemlere bu tekniklerle çözüm üretmeye çalışmaya ek olarak, değer zincirinin her halkası için aynı teknikleri uyarlamaya çalışmak faydalı olacaktır.

Yönetimde şeffaflık sağlanmalıdır. Alınan karar ve politikaların pazar ve çalışanlarla paylaşılması ile stratejik yönetim daha işlevsel hâle gelir. Her çalışanın görüşüne değer verilmelidir. Her türlü şikayet ve geri bildirimlerin daha aktif bir bilgi ağı oluşturularak sağlanması gerekir. 


\section{KAYNAKÇA}

Albanese, R. (1988), Management, Ohio: South Western Publishing.

Alsudiri, T., W. Al-Karaghouli, T. Eldabi (2013), "Alignment of Large Project Management Process to Business Strategy: A Review and Conceptual Framework," Journal of Enterprise Information Management, 26(5), 596-615, https://doi.org/10.1108/JEIM-072013-0050

Antony, J., A.S. Bhuller, M. Kumar, K. Mendibil, D.C. Montgomery (2012), “Application of Six Sigma DMAIC Methodology in a Transactional Environment," International Journal of Quality \& Reliability Management, 29(1), 31-53, https://doi.org/10.1108/02656711211190864.

Artto, K., M. Martinsuo, P. Dietrich, J. Kujala (2008), "Project Strategy: Strategy types and their Contents in Innovation Projects," International Journal of Managing Projects in Business, 1(1): 49-70, https://doi.org/10.1108/17538370810846414

Artto, K., T. Ahola, R. Kyrö, A. Peltokorpi (2017), "Managing Business Networks for Value Creation in Facilities and their External Environments: A Study on Co-Location," Facilities, 35(1/2), 99-115, https://doi.org/10.1108/F-07-2015-0049.

Bhatnagar, R., , C.C. Teo (2009), "Role of logistics in Enhancing competitive Advantage: A Value Chain Framework for Global Supply Chains," International Journal of Physical Distribution \& Logistics Management, 39(3), 202-226, https://doi.org/10.1108/09600030910951700.

Blackman, I.D., C. Holland (2006), "The Management of Financial Supply Chains: from Adversarial to co-Operative Strategies,” in: Suomi, R., Cabral, R., Hampe, J., Heikkila, A., Jarvel " ainen, J., Koskivaara, E. (Eds.), Project E-Society: Building " Bricks. Springer, New York, 82-95.

Böhm, A. (2008), The Swot Analysis, Grin Verlag.

Cochran, C. (2006), Becoming a Customer-focused Organization, Paton Professional.

Crain, D.W., S. Abraham (2008), "Using value-chain analysis to discover customers' strategic needs," Strategy \& Leadership, 36(4), 29-39, https://doi.org/10.1108/10878570810888759.

Deming, W.E. (2000), Out of the Crisis, The MIT Press.

Deniz, E. (2009), Otomotiv Sektör Raporu, Avrupa İşletmeler Ağı- Karadeniz, 1- 31.

Engelbrecht, J., K.A Johnston, V. Hooper (2017), "The influence of business managers' IT competence IT project success," International Journal of Project Management, 35: 994-1005.

Eraslan, H.K.B. (2008), "Değer Zinciri (Value Chain) Yöntemi ile Türk Tekstil ve Hazırgiyim Sektörünün Değerlendirilmesi," Afyon Kocatepe Üniversitesi, İI.̇.B.F. Dergisi, 10(2), 307-332.

Ferrel, O.C., M. Hartline (2012), Marketing Strategy, Cengage Learning.

Gall, M.D., W.R. Barg, J.P. Gall (1996), Educational Research: an Introduction (Sixth ed.), New York: Longman. 
Gardner, R.A. (2004), The Process-focused Organization: A Transition Strategy for Success, ASQ Quality Press.

Gerring, J. (2004), What is a case study and what is it good for?, American Political Science Review, 98, 341-354.

Gillham, B. (2000), Case Study Research Methods, London: Continuum.

Gupta, P., R.K. Jain, U. Dhar (2007), Enhancing Enterprise Competitiveness: (Marketing, People, IT and Entrepreneurship), Allied Publishers.

Harris, D.H. (1994), Organizational Linkages: Understanding the Productivity Paradox, National Academies Press.

Heneric, O., G. Licht, S. Lutz, W. Urban (2005), "The European Automotive Industry in a Global Context,” in: Heneric, O., Licht, G., Sofka, W. (Eds.), Europe's Automotive Industry on the Move. Springer, Heidelberg, Germany, 5-43.

Howieson, J., M. Lawley, K. Hastings (2016), "Value chain analysis: an iterative and relational approach for agri-food chains,” Supply Chain Management: An International Journal, 21(3): 52-362, https://doi.org/10.1108/ SCM-06-2015-0220.

IMA (Institute of Management Accountants), Arthur Andersen LLP (1999), Statements on Management Accounting: Theory of Constraints(TOC) Management System Fundamentals, IMA Publication.

Imai, M. (2012), Gemba Kaizen: A Commonsense Approach to a Continuous Improvement Strategy, Second Edition, McGraw Hill Professional.

Jan, T. S., C.T. Hsiao (2004), “A Four-Role Model of the Automotive Industry Development in Developing Countries: A Case in Taiwan," The Journal of the Operational Research Societ, 55(11), 1145-1155.

Janssen, M., H.G. Sol (2000), "Evaluating the Role of Intermediaries in the Electronic Value Chain," Internet Research, 10(5), 406-417, https://doi.org/10.1108/10662240010349417.

Kobu, B. (1993), Üretim Yönetimi, Avcıl Basım Yayın.

Kuyucak, F., Y. Şengür (2009), "Değer Zinciri Analizi: Havayolu İşletmeleri İçin Genel Bir Çerçeve,” KMU İ̈BF Dergisi, 11(16), 132-147.

Lind, L., M. Pirttila, S. Viskari, F. Schupp, T. Karri (2012), "Working Capital Management in the Automotive Industry: Financial Value Chain Analysis," Journal of Purchasing and Supply Management, 18(2), 92-100.

Marksberry, P. (2011), “The Toyota Way - a Quantitative Approach,” International Journal of Lean Six Sigma, 2(2), 132-150, https://doi.org/10.1108/20401461111135028

Monden, Y., N. Imai, T. Matsuo, N. Yamaguchi (2013), Management of Service Businesses in Japan, World Scientific.

Nieto- Rodriguez, A. (2012), The Focused Organization: How Concentrating on a Few Key Initiatives Can Dramatically Improve Strategy Execution, Gower Publishing, Ltd.

OSD (2015), Aylık Istatistiki Bilgiler Bülteni, http://www.osd.org.tr/sites/1/upload/files/Bulten2015-12-60.pdf, ET: 25.04.2017 
OSD (2017), Otomotiv Sanayii Genel ve İstatistik Bülteni, http://www.osd.org.tr/sites/1/upload/files/Yillik_2017-2224.pdf, ET: 24.04.2017

Patton, M.Q. (1990), Qualitative evaluation and research methods (Second Ed.), London: Sage Publication

Patton, M.Q. (1987), How to Use Qualitative Methods in Evaluation, Sage Publications.

Porter, M.E. (1985), Competitive Advantage: Creating and Sustaining Superior Performance, Simon and Schuster.

Porter, M.E. (1986), Competition in Global Industries, Harvard Business Press.

Porter, M.E. (2008), On Competition, Harvard Business Press.

Porter, M.E., Teisberg, E. O. (2006), Redefining Health Care: Creating Value-based Competition on Results, Harvard Business Press.

Punch, K.F. (2005), Introduction to Social Research-Quantitative \& Qualitative Approaches, London: Sage.

Raia, A.R. (1963), A Case Study of The Effects of Goal-Setting And Self-Control on Organization Performance, UCLA.

Ruhl J.M. (1997), The Theory of Constraints within a Cost Accounting Framework, Journal of Cost Management, 11(6), 16- 25.

Schmidt, M.J., M.S. Gary (2002), Combining System Dynamics And Conjoint Analysis For Strategic Decision Making with Automotive High-Tech SME. Syst Dy'nam, 18, 359379.

Shekhar, S. (2010), Business Policy and Strategic Management, I. K. International Pvt Ltd.

Suchman L.A. (1987), Plans and Situated Actions. The Problem of Human-Machine Communication. Cambridge: Cambridge University Press.

Takahashi, S., D. Sallach, J. Rouchier (2007), Advancing Social Simulation: The First World Congress, Springer Science \& Business Media.

Taylor, D.H. (2005), Value Chain Analysis: an Approach to Supply Chain Improvement in Agri-Food Chains, International Journal of Physical Distribution \& Logistics Management, 35(10), 744-761, https://doi.org/10.1108/09600030510634599.

Taylor, D.H., A. Fearne (2009), "Demand Management in fresh food Value Chains: A Framework for Analysis and Improvement," Supply Chain Management: An International Journal, 14(5): 79-392, https:// doi.org/10.1108/13598540910980297.

Türnüklü, A. (2001), "Eğitimbilim Alanında Aynı Araştırma Sorusunu Yanıtlamak İçin Farklı Araştırma Tekniklerinin Birlikte Kullanılması,” Eğitim ve Bilim, 26(120), 8-13.

Wheelen, T.L., D.J. Hunger (2002), Strategic Management and Business Policy, Eighth ed. Prentice-Hall, Pearson Education Limited, New Jersey.

Y1lmaz, Y., U.S. Bititci (2006), "Performance Measurement in Tourism: A Value Chain Model," International Journal of Contemporary Hospitality Management, 18(4): 41-349, https:// doi.org/10.1108/09596110610665348.

Yin, R.K. (2009), Case Study Research, Design and Methods, $3^{\text {rd }}$ ed. Thousand Oaks: Sage Publications. 
Ekler

Ek1. Araştırmada Kullanılan Yapılandırılmış Sorular

\begin{tabular}{|c|c|}
\hline \multicolumn{2}{|c|}{$\begin{array}{l}\text { 1. Temel Faaliyetler } \\
\text { 1.1. Tedarik Lojistiği }\end{array}$} \\
\hline & $\begin{array}{l}\text { Üretimini yaptığınız otobüslerin bileşenlerini olușturan temel maddelerin işletmeye kabulü, } \\
\text { depolama, girdilerin ürüne dağıtımı ile ilgili faaliyetleriniz nelerdir? }\end{array}$ \\
\hline & Bunu bir süreç olarak düşünecek olursanız şirket olarak hangi konulara önem vermektesiniz? \\
\hline \multicolumn{2}{|r|}{ 1.2. Operasyon/ İșlem } \\
\hline & Otobüsün nihai ürüne dönüşmesini sağlayan girdilerle ilgili faaliyetler nelerdir? \\
\hline & Bu faaliyetlerde işletmenizi öne çıkaran bir uygulamanız var mı? \\
\hline \multicolumn{2}{|c|}{ 1.3. Sevkiyat Lojistiği } \\
\hline \multicolumn{2}{|r|}{ 1.4. Pazarlama ve Satış } \\
\hline & $\begin{array}{l}\text { Müşterilerinizin ya da tüketicilerin ürününüz olan otobüsleri satın almaları için neler } \\
\text { yapmaktasınız? }\end{array}$ \\
\hline & Pazarlama ve satış anlamında sizi siz yapan değerler nelerdir? \\
\hline & İşletmenizin pazarlama ve satış verileri hakkında bilgi verebilir misiniz? \\
\hline & Küresel müşterileriniz var mı? \\
\hline \multicolumn{2}{|c|}{ 1.5. Hizmet } \\
\hline & $\begin{array}{l}\text { Ürettiğiniz otobüslerin değerinin geliştirilmesi ve sürekliliğinin sağlanması için ne gibi faaliyetler } \\
\text { gerçekleştirmektesiniz? }\end{array}$ \\
\hline & Müşteri şikayetleri konusunda neler yapıyorsunuz? \\
\hline & Satış Sonrası Hizmetleriniz nelerdir? \\
\hline \multirow{2}{*}{\multicolumn{2}{|c|}{$\begin{array}{l}\text { 2. Destek Sağlama Faaliyetleri } \\
\text { 2.1. Tedarik }\end{array}$}} \\
\hline & \\
\hline & $\begin{array}{l}\text { Ürettiğiniz otobüsün müşteriye teslim sürecine kadar işletmeye ve ürüne katkı sağlayacak destek } \\
\text { faaliyetleriniz var mı? }\end{array}$ \\
\hline \multicolumn{2}{|r|}{ 2.2. Teknoloji Geliștirme } \\
\hline & Teknoloji geliştirme faaliyetleriniz nelerdir? \\
\hline & Ürettiğiniz otobüslerin genel özelliklerinden bahsedebilir misiniz? \\
\hline & Ar- Ge' den bahsettiniz. Konuyu biraz açabilir misiniz? \\
\hline \multicolumn{2}{|c|}{ 2.3. İnsan Kaynakları Yönetimi } \\
\hline & İnsan kaynakları politikanız var mı? Nelerdir? \\
\hline & $\begin{array}{l}\text { İnsan kaynakları işe alım bağlamında ve izlediğiniz politikalar çerçevesinde belirli bir süreç izliyor } \\
\text { musunuz? Bu süreçler nelerdir? }\end{array}$ \\
\hline & Çalışanlarınızın demografik bilgileri hakkında biraz bilgi verebilir misiniz? \\
\hline \multicolumn{2}{|r|}{ 2.4. İşletme Altyapısı } \\
\hline & İşletme altyapınız hakkında bilgi verebilir misiniz? \\
\hline & İşs sağlığı ve güvenliği ile çevre hakkında işletmenin yaklaşımı nedir? \\
\hline & Toplam kalite yaklaşımından bahsettiniz, bu konu hakkında bilgi verebilir misiniz? \\
\hline & İşletmenizin stratejik hedefleri nelerdir? \\
\hline & Risk yönetiminden bahsettiniz, böyle bir sisteminiz var mı? Kısaca izah etmeniz mümkün mü? \\
\hline & Bilgi güvenliğini nasıl sağlıyorsunuz? \\
\hline
\end{tabular}

